\title{
Adsorption of ammonium, nitrite, and nitrate onto rice husk biochar for nitrogen removal
}

\author{
Vo Thi Minh Thao ${ }^{1 *}$, Nguyen Thi Canh ${ }^{2}$, Nguyen Lu Nguyet Hang ${ }^{2}$, Nguyen Minh Khanh $^{1}$, \\ Nguyen Ngoc Phi ${ }^{1}$, Pham Thi Ai Niem ${ }^{1}$, Tran Tuan Anh ${ }^{1}$, Nguyen Thi Hanh Nguyen ${ }^{1}$, \\ Nguyen Tan Duc ${ }^{1}$
}

${ }^{1}$ Biotechnology Center of Ho Chi Minh City, Vietnam

${ }^{2}$ Ho Chi Minh City University of Technology, Vietnam

*Corresponding author: vothiminhthao1993@gmail.com

\begin{tabular}{|c|c|}
\hline ARTICLE INFO & ABSTRACT \\
\hline $\begin{array}{l}\text { DOI:10.46223/HCMCOUJS. } \\
\text { tech.en.11.1.1622.2021 }\end{array}$ & $\begin{array}{l}\text { This study aims to investigate the adsorption capacity of } \\
\text { ammonium } \mathrm{NH}_{4}^{+} \text {, nitrite } \mathrm{NO}_{2}^{-} \text {and nitrate } \mathrm{NO}_{3}^{-} \text {onto rice husk } \\
\text { biochar (RHB) obtained from } 550{ }^{\circ} \mathrm{C} \text { pyrolysis temperature in the } \\
\text { context of using low-cost absorbent for recirculating aquaculture } \\
\text { system (RAS). Raw RHB at its original size } 5-8 \mathrm{~mm} \text { has been chosen }\end{array}$ \\
\hline Received: March $17^{\text {th }}, 2021$ & for testing its adsorption capacity as well as several key material \\
\hline Revised: March 24 ${ }^{\text {th }}, 2021$ & $\begin{array}{l}\text { properties ( } \mathrm{pH} \text { PZC, surface area, and elemental analysis). From } \\
\text { surface functional group analysis, there existed the } \mathrm{O}-\mathrm{H} \text { group (at }\end{array}$ \\
\hline Accepted: March $24^{\text {th }}, 2021$ & $\begin{array}{l}\left.\text { frequency } 3443 \mathrm{~cm}^{-1}\right),-\mathrm{CH}_{3}\left(2360 \mathrm{~cm}^{-1}\right) \text {, and either }-\mathrm{C}=\mathrm{O} \text { or } \mathrm{C}=\mathrm{C} \\
\left.\text { group (in the range of frequency } 1600-1650 \mathrm{~cm}^{-1}\right) \text { as well as }-\mathrm{COOH} \\
\left(1456 \mathrm{~cm}^{-1}\right) \text { that helped enhance chemical adsorption. The } \\
\text { experimental adsorption data has been roughly consistent with } \\
\text { Langmuir and Freundlich models that used to calculate the maximum } \\
\text { saturated monolayer adsorption capacity } \mathrm{Q}^{0}{ }_{\text {max }} \text { of ammonium, nitrite, }\end{array}$ \\
\hline Keywords: & and nitrate were $0.1003,0.2477$, and $0.1290 \mathrm{mg} / \mathrm{g}$ respectively. \\
\hline $\begin{array}{l}\text { adsorption, biochar, } \\
\text { Langmuir, Freundlich, } \\
\text { nitrogen compound }\end{array}$ & $\begin{array}{l}\text { Therefore, RHB could be a potential candidate for biofilter } \\
\text { application in both targets cost-efficient and sustainable that worth } \\
\text { applied at scale. }\end{array}$ \\
\hline
\end{tabular}

\section{Introduction}

Ensuring food security is always on top priority in any sustainable development framework (FAO, 2020). In particular, aquaculture together with livestock and crop farming are considered as three pillars of the global food production system (Gladek et al., 2017). Nevertheless, the aquaculture industry poses many issues that need to be addressed from water quality, aquatic juveniles and feed formulations. Recirculating aquaculture system (RAS) has been developed to tackle the primary problem relating to water saving in terms of protecting aquatic animal health and decreasing environmental impact from aquaculture activities (Takeuchi, 2017; Timmons, Guerdat, \& Vinci, 2018). Despite continuous improvement through years, there are still major issues within RAS themselves such as biofilter, nitrogen removal, denitrification device as well as protein skimmer which needed to research for better efficient, eco-friendly and low-cost solutions. (Badiola, Mendiola, \& Bostock, 2012). On the other hand, biochar recently emerged as a green adsorbent as well as a disposal filter in biological wastewater treatment mainly for bioretention and bioremediation (Ahmed \& Hussain, 2018; Crini \& Lichtfouse, 2018; Ferreira, Calisto, Otero, Nadais, \& Esteves, 2016; Poor \& Mohamed, 2020; Wu et al., 2020). Because biochar is a stable 
carbon-rich material derived from thermal pyrolysis of biomass, it has been regarded as an economical and sustainable carrier which has extensive application prospects in the field of soil improvement or wastewater treatment. Also, there have been many studies on the efficacy of biochar as a support medium during anaerobic/aerobic digestion or a support-based catalyst for biodegradation of recalcitrant contaminants (Enaime, Baçaoui, Yaacoubi, \& Lübken, 2020; Lehmann \& Joseph, 2015; Wu et al., 2020). Depending on pyrolysis temperatures and postpreparation methods, biochar could be engineered to obtain new valued properties such as higher surface area, micropore volume and specific functional groups that become more suitable for different inorganic/organic substances sorption even for metal immobilization (Enaime et al., 2020; Huang et al., 2016; Mohan, Sarswat, Ok, \& Pittman, 2014; Wang et al., 2015). In this work, we study on the capacity adsorption of rice husk biochar (RHB) for nitrogen compounds such as ammonium $\mathrm{NH}_{4}{ }^{+}$, nitrite $\mathrm{NO}_{2}{ }^{-}$and nitrate $\mathrm{NO}_{3}{ }^{-}$to gain more insights about mechanism behind that could be used to improve nitrogen removal process. In Vietnam, researches on biochar and its nearest relative (hydrochar) for wastewater treatment are very active that focus on the modification of biochar surface in order to increase adsorption capacity for organic species as well as heavy metal (Bui, 2016; Nguyen et al., 2021; Pham, 2016; Vu \& Trinh, 2016). Several critical papers that provide us a solid explanation on the process of removing organic contaminants by adsorption mechanism of biochar including electrostatic attraction, pore-filling, $\pi-\pi$ electron-donor acceptor interaction, H-bonding, complexes adsorption, hydrophobic interactions and so on that wellwritten in recent studies (Ahmad et al., 2014; Dai, Zhang, Xing, Cui, \& Sun, 2019; Liang, Yu, Huang, Zhang, \& Cao, 2016; Tran, You, Hosseini-Bandegharaei, \& Chao, 2017; Zhang et al., 2020). Among many mathematical models have been developed for prediction and interpretation of adsorption mechanism such as isotherm equation, kinetic model, and thermodynamic constant beside calculation the effects of contact time, $\mathrm{pH}$ of aqueous solution as well as functional groups which caused by pre- and post-treatment methods being applied to the adsorbent, we focus on two main points that help introduce rice husk biochar into nitrogen removal application. There are to analysis the functional groups and to apply isotherm models on experimental data for estimation about either the nature of our studied biochar and maximum saturated monolayer adsorption capacity $\mathrm{Q}^{0}{ }_{\text {max }}$ of ammonium, nitrite, and nitrate onto RHB that would be useful to design an economical but effective biological filtration for RAS.

\section{Materials and methods}

\subsection{Biochar preparation}

Rice husk biochar (RHB) was produced by putting rice husk in an inox box wrapped by aluminum foil for creating a limited oxygen condition during slow pyrolysis process in a furnace (Nabertherm) with heating rate $10{ }^{\circ} \mathrm{C} / \mathrm{min}$ from beginning to $550{ }^{\circ} \mathrm{C}$ and held for 3 hours (Fidel, Laird, \& Spokas, 2018). For the purpose to use raw RHB as biofilter substrate in trickling filtration so its original size (5-8 mm) was selected for adsorption experiments in awareness that this particle size may lessen adsorption efficiency if compared with powder size. To prepare RHB as adsorbent, we followed the acid-washing method (Fidel et al., 2018). Biochar after treatment was dried at 60 ${ }^{\circ} \mathrm{C}$ for testing adsorption capacity.

\subsection{Biochar characterization}

The $\mathrm{pH}$ and EC values of raw RHB were measured by using ratio 1:20 w/v biochar and deionized water (DI water) followed IBI guidelines (International Biochar Initiative, 2015; Inyang et al., 2012). pHPZC value was determined using salt addition method (Bakatula, Richard, Neculita, $\&$ Zagury, 2018). It is essential to remind that the point of zero charge $\left(\mathrm{pH}_{\mathrm{PZC}}\right)$ is the $\mathrm{pH}$ value at which the net charge on material surface becomes zero. When $\mathrm{pH}_{\mathrm{PZC}}<\mathrm{pH}$ of the solution, the 
biochar surface will be negatively charged that possibly attracts cations better, likewise, when the $\mathrm{pH}_{\mathrm{PZC}}>\mathrm{pH}$ of the solution, the surface becomes positively charged that might attracts anions effectively (Essandoh, Kunwar, Pittman, Mohan, \& Mlsna, 2015; Herath et al., 2016). To measure surface area and observation the microscopic shape of RHB, the BET and SEM method also undertaken. The surface functional groups of RHB have been characterized by the FTIR spectroscopy (Bruker Tensor 27) for explanation the adsorption process by chemical reactions. In addition, elemental analysis of the studied RHB was conducted using SEM-EDS method. For determination of ammonium $\mathrm{NH}_{4}{ }^{+}$, nitrite $\mathrm{NO}_{2}^{-}$, and nitrate $\mathrm{NO}_{3}{ }^{-}$in the filtrates, we followed Nessler method (ASTM D1426-15), Griess assay (TCVN 6178:1996), and spectrometric method using sulfosalicylic acid (TCVN 6180:1996) respectively.

\subsection{Batch adsorption experiments}

\subsubsection{Ammonium adsorption onto RHB}

Ammonium solutions with concentration varying from 0.5-1-2-4-6 (mg $\left.\mathrm{NH}_{4}^{+} / \mathrm{L}\right)$ were prepared by diluted $\left(\mathrm{NH}_{4}\right)_{2} \mathrm{SO}_{4}$ in DI water. Adsorption experiments were conducted by putting 1 g RHB inside a $50 \mathrm{~mL}$ centrifuge tube containing $20 \mathrm{~mL}$ ammonium solution accordingly. Control treatment was conducted the same procedure using DI water without adding absorbate solution. These centrifuge tubes were shaked at $200 \mathrm{rpm}$ and $28{ }^{\circ} \mathrm{C}$ then analysized ammonium concentration in the filtrates using filter papers (Sartorius ${ }^{\circledR} 292$ ) for each time interval 0.5-1-2-34-5-6-8-16-24 hours. Every ammonium concentration and time point were triplicate. From empirical data, we fitted them on isotherm equations and calculated the maximum saturated monolayer adsorption capacity $\mathrm{Q}^{0}{ }_{\text {max }}$ of studied adsorbate (Shukla, Sahoo, \& Remya, 2019).

Adsorption capacity at time:

$$
q_{t}=\frac{\left(C_{0}-C_{t}\right)}{m} \times V
$$

where, $\mathrm{q}_{\mathrm{t}}(\mathrm{mg} / \mathrm{g})$ is the adsorption capacity at time, $\mathrm{C}_{0}(\mathrm{mg} / \mathrm{L})$ and $\mathrm{C}_{\mathrm{t}}(\mathrm{mg} / \mathrm{L})$ are the adsorbate concentrations at beginning and at time, respectively; $\mathrm{m}(\mathrm{g})$ is the mass of adsorbent used, $\mathrm{V}(\mathrm{L})$ is the volume of the adsorbate solution.

Adsorption capacity at equilibrium:

$$
q_{e}=\frac{\left(C_{0}-C_{e}\right)}{m} \times V
$$

where, $\mathrm{q}_{\mathrm{e}}(\mathrm{mg} / \mathrm{g})$ is the adsorption capacity at equilibrium, $\mathrm{C}_{0}(\mathrm{mg} / \mathrm{L})$ and $\mathrm{C}_{\mathrm{e}}(\mathrm{mg} / \mathrm{L})$ are the adsorbate concentrations at beginning and at equilibrium, respectively; $\mathrm{m}(\mathrm{g})$ and $\mathrm{V}(\mathrm{L})$ were described above.

For studying on adsorption mechanism, Langmuir and Freundlich adsorption model were used with the assumptions that homogeneous surface sites or heterogeneous surface sites respectively that would be the main nature of a particular adsorbent (Wan et al., 2012).

Langmuir adsorption isotherm equation (Bolster \& Hornberger, 2007; Ghosal \& Gupta, 2017; Langmuir, 1918; Tran et al., 2017)

$$
q_{e}=\frac{Q_{\max }^{0} \times K_{L} \times C_{e}}{1+K_{L} \times C_{e}}
$$


where, $\mathrm{q}_{\mathrm{e}}(\mathrm{mg} / \mathrm{g})$ is the adsorption capacity at equilibrium, $\mathrm{C}_{\mathrm{e}}(\mathrm{mg} / \mathrm{L})$ is the adsorbate concentration at equilibrium, $\mathrm{Q}^{0}{ }_{\text {max }}(\mathrm{mg} / \mathrm{g})$ is the maximum saturated monolayer adsorption capacity of an adsorbent, $\mathrm{K}_{\mathrm{L}}(\mathrm{L} / \mathrm{mg})$ is the Langmuir constant related to the affinity between an adsorbent and adsorbate. When the experimental equilibrium data are adequately described by the Langmuir model, it is necessary to calculate the separation factor (Foo \& Hameed, 2010).

$$
R_{L}=\frac{1}{1+K_{L} \times C_{0}}
$$

where, $\mathrm{R}_{\mathrm{L}}$ is a constant separation factor (dimensionless) of a solid-liquid adsorption system, $\mathrm{K}_{\mathrm{L}}$ ( $\mathrm{L} / \mathrm{mg}$ ) is the Langmuir equilibrium constant, and $\mathrm{C}_{0}$ is the initial adsorbate concentration. The isotherm shape was used to predict whether the adsorption system was favorable, unfavorable, linear, or irreversible according to $\mathrm{R}_{\mathrm{L}}$ value shown in Table 1.

* Freundlich adsorption isotherm equation (Appel, 1973; Freundlich, 1907; Tran et al., 2017; Van der Bruggen, 2015)

$$
q_{e}=K_{F} \times \mathrm{C}_{e}^{1 / n}
$$

where, $\mathrm{q}_{\mathrm{e}}(\mathrm{mg} / \mathrm{g})$ is the adsorption capacity at equilibrium, $\mathrm{C}_{\mathrm{e}}(\mathrm{mg} / \mathrm{L})$ is the adsorbate concentration at equilibrium, $\mathrm{K}_{\mathrm{F}}$ is the constant characterizes the strength of adsorption between an adsorbent and adsorbate, $\mathrm{n}$ is a dimensionless intensity parameter.

\section{Table 1}

Relationship between isotherm parameters and isotherm shapes (Tran et al., 2017; Worch, 2012, p. 52, p. 76)

\begin{tabular}{|c|c|c|c|}
\hline Freundlich exponent & Separation factor & Isotherm shape & Remark \\
\hline $1 / \mathrm{n}=0$ & $\mathrm{R}_{\mathrm{L}}=0$ & Irreversible & Horizontal \\
\hline $1 / \mathrm{n}<1$ & $\mathrm{R}_{\mathrm{L}}<1$ & Favorable & Concave \\
\hline $1 / \mathrm{n}=1$ & $\mathrm{R}_{\mathrm{L}}=1$ & Linear & Linear \\
\hline $1 / \mathrm{n}>1$ & $\mathrm{R}_{\mathrm{L}}>1$ & Unfavorable & Convex \\
\hline
\end{tabular}

Note: $1 / \mathrm{n}$ calculated from (5); RL calculated from (4)

Source: The researcher's data analysis

\subsubsection{Nitrite adsorption onto $R H B$}

Nitrite solutions with concentration varying from $0.1-1-3-6-10\left(\mathrm{mg} \mathrm{NO}_{2}{ }^{-} / \mathrm{L}\right)$ were prepared by diluted $\mathrm{NaNO}_{2}$ in DI water. Experiment setup was followed the same ammonium adsorption procedure described in 2.3.1.

\subsubsection{Nitrate adsorption onto $R H B$}

Similarly, nitrate solutions with concentration varying from 3-3.5-4-8-10 $\left(\mathrm{mg} \mathrm{NO}_{3}{ }^{-} / \mathrm{L}\right)$ were prepared by diluted $\mathrm{KNO}_{3}$ in DI water. Experiment setup was followed the same ammonium adsorption procedure described in 2.3.1.

\subsection{Statistical analysis}

Adsorption data was stored and calculated by Excel then fitted using OriginPro for Langmuir and Freundlich models. 


\section{Results and discussions}

\subsection{Rice husk biochar properties}

Biochar derived from rice husk after pyrolysis at $550{ }^{\circ} \mathrm{C}$ has $\mathrm{pH}$ and $\mathrm{EC}$ values before and after acid-washing around $10.10 \pm 0.03$ and $0.28 \pm 0.01 \mathrm{mS} / \mathrm{cm}$ in compared with $6.11 \pm 0.05$ and $0,11 \pm 0,01 \mathrm{mS} / \mathrm{cm}$ respondingly. From this result, acid-washing is an effective approach for neutralizing biochar for getting accuracy in applied for adsorption experiment (Fidel et al., 2018). The $\mathrm{pH}_{\mathrm{PZC}}$ of this studied RHB was 6.8 also being similar with the result of Herath et al. (2016). Our biochar has surface area $42.22 \mathrm{~m}^{2} / \mathrm{g}$ that was higher than other RHBs in related studies (Kizito et al., 2015; Milla, Rivera, Huang, Chien, \& Wang, 2013). Morphology of biochar at scale $\times 3000$ has clearly shown that it was a rich-porous material with many macro and micropores that obviously enhance the pollutant adsorption by both physical and chemical process. From surface functional group analysis, there existed the $\mathrm{O}-\mathrm{H}$ group (at frequency $\left.3443 \mathrm{~cm}^{-1}\right),-\mathrm{CH}_{3}\left(2360 \mathrm{~cm}^{-}\right.$ ${ }^{1}$ ), and either $-\mathrm{C}=\mathrm{O}$ or $\mathrm{C}=\mathrm{C}$ group (in the range of frequency $\left.1600-1650 \mathrm{~cm}^{-1}\right),-\mathrm{COOH}(1456$ $\left.\mathrm{cm}^{-1}\right)$ as well as $\mathrm{CO}_{3}{ }^{2-}\left(1098\right.$ and $\left.795 \mathrm{~cm}^{-1}\right)$. Elemental analysis of the studied RHB was C (10.19\%), O (52.74\%), Al (0.38\%), Si (36.16\%), and K (0.53\%). A number of aromatic functional groups in biochar structure also appeared after pyrolysis that will contribute to adsorption capacity (Brewer, Schmidt-Rohr, Satrio, \& Brown, 2009).

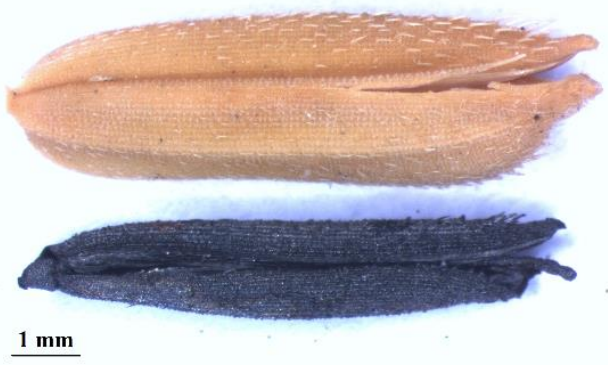

$\operatorname{Bar}=1 \mathrm{~mm}$

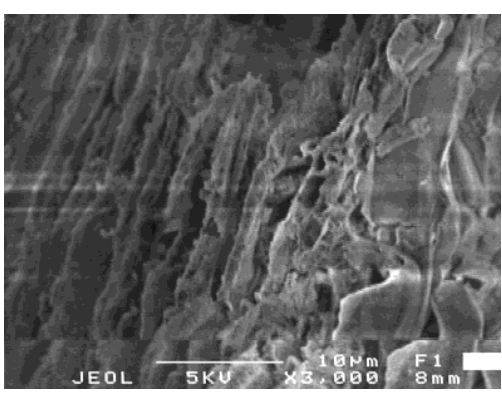

$\operatorname{Bar}=10 \mu \mathrm{m}$

Figure 1. Left: Image of rice husk and its biochar under stereo microscope.

Right: SEM image of RHB

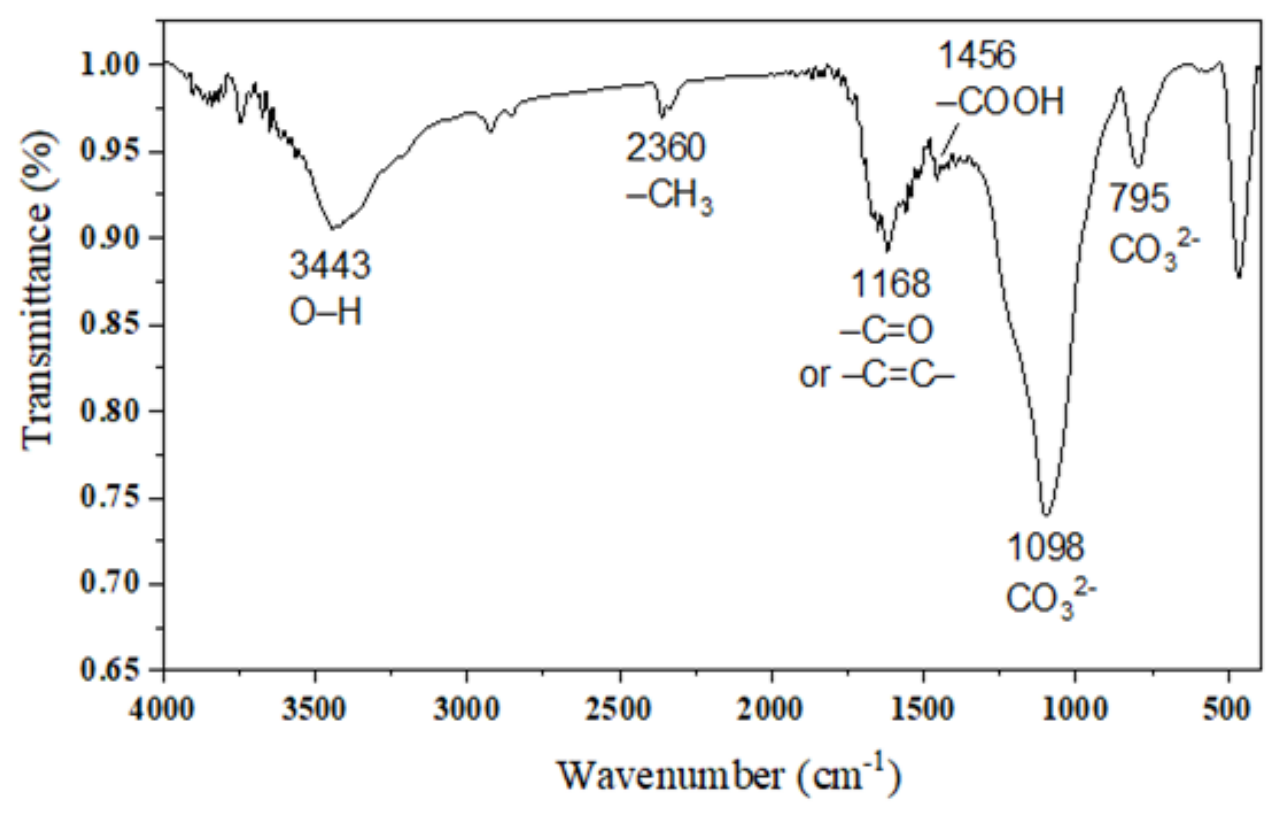

Figure 2. FTIR spectrum of the studied RHB 
For ammonium adsorption, it is solely influenced by cation exchange, surface complexation with oxygen-containing functional groups as described by Cui, Hao, Zhang, He, and Yang (2016). Additionally, ammonium adsorption is $\mathrm{pH}$-dependent with optimum values 7-7.5 (Fidel et al., 2018). Freundlich equation has been found that more suitable for describing the ammonium adsorption mechanism than Langmuir equation that implies there is heterogeneous adsorption of the multi molecular layer (Gai et al., 2014; Hu et al., 2020; Kizito et al., 2015; Liang et al., 2016). Nitrite and nitrate adsorption are anions that could be adsorbed to positively charged surface by electrostatic attraction when $\mathrm{pH}$ of aqueous solution $<\mathrm{pH}$ PzC. Functional groups such as $-\mathrm{COOH}$ and $\mathrm{O}-\mathrm{H}$ linked with phenolic groups or metals that attached on biochar were identified the main machenism for chemical adsorption of nitrite and nitrate onto biochar (Afkhami, Madrakian, \& Karimi, 2007; Hafshejani et al., 2016; Yakout \& Mostafa, 2014; Zhang et al., 2020).

\subsection{Adsorption isotherm}

\subsubsection{Ammonium adsorption}

When increasing the initial ammonium concentration, there was a trend that adsorption capacity increases accordingly and reached an equilibrium around 16-hour contact time. Table 1 was used to check the validity of isotherms. The separation factor $\left(\mathrm{R}_{\mathrm{L}}\right)$ of Langmuir equation ranged 0.66-0.96 and Freundlich exponent (1/n) was 0.81 that means both isotherms suitable for explaining the ammonium adsorption onto RHB. $\mathrm{R}^{2}(0.9762)$ of Freundlich equation was higher than $\mathrm{R}^{2}(0.9716)$ of Langmuir equation so that the behavior of the ammonium adsorption of this studied RHB followed the heterogeneous adsorption of the multi molecular layer rather than mono layer (Kizito et al., 2015).

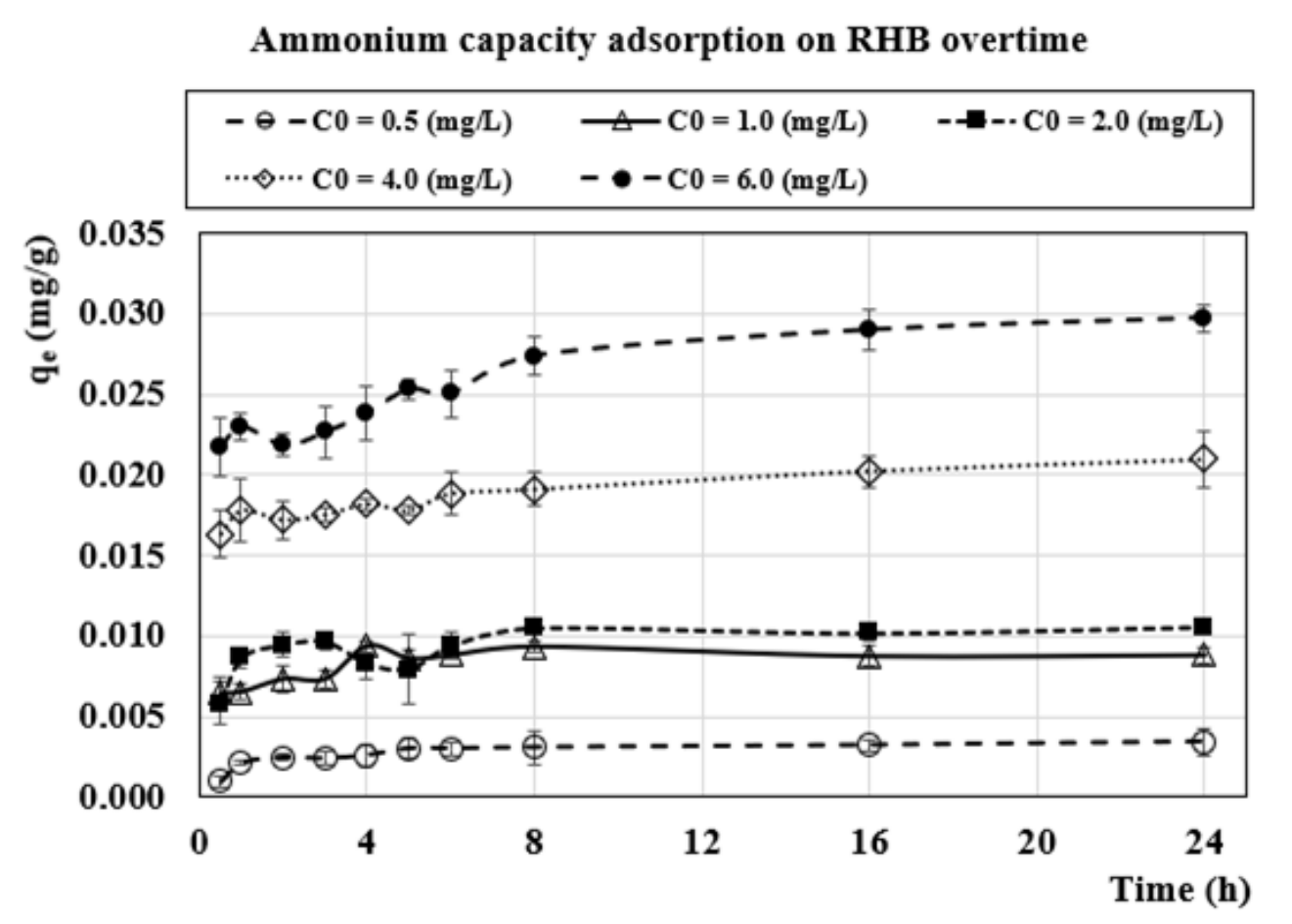

Figure 3. Effect of contact time and initial concentration to ammonium adsorption capacity onto RHB 


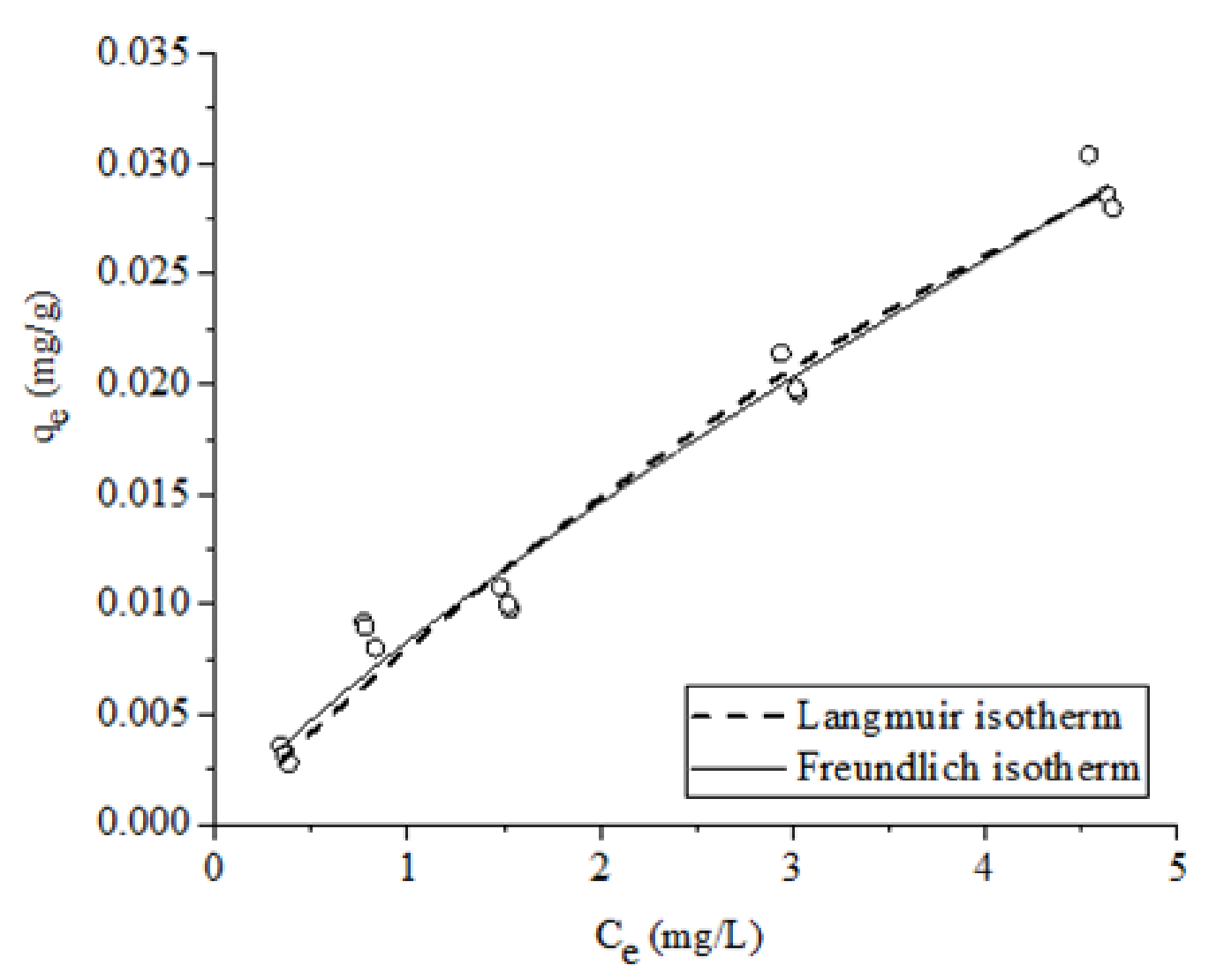

Figure 4. Langmuir and Freundlich isotherms for ammonium adsorption onto RHB

\section{Table 2}

Langmuir and Freundlich parameters for ammonium adsorption onto RHB at $28{ }^{\circ} \mathrm{C}$

\begin{tabular}{cccccc}
\hline & \multicolumn{3}{c}{ Langmuir isotherm } & \multicolumn{3}{c}{ Freundlich isotherm } \\
\hline $\mathrm{Q}^{0}{ }_{\max }(\mathrm{mg} / \mathrm{g})$ & $\mathrm{K}_{\mathrm{L}}(\mathrm{L} / \mathrm{mg})$ & $\mathrm{R}^{2}$ & $\mathrm{~K}_{\mathrm{F}}$ & $\mathrm{n}$ & $\mathrm{R}^{2}$ \\
\hline 0.1003 & 0.0867 & 0.9716 & 0.0083 & 1.2325 & 0.9762 \\
\hline
\end{tabular}

Source: The researcher's data analysis

\subsubsection{Nitrite adsorption}

When increasing the initial nitrite concentration, there was a trend that adsorption capacity increases accordingly and reached an equilibrium at 16-hour contact time. Table 1 was used to check the validity of isotherms. The separation factor $\left(\mathrm{R}_{\mathrm{L}}\right)$ of Langmuir equation ranged 0.08-0.90 and Freundlich exponent $(1 / \mathrm{n})$ was 0.56 that means both isotherms suitable for explaining the nitrite adsorption onto RHB. $\mathrm{R}^{2}(0.9090)$ of Langmuir equation was higher than $\mathrm{R}^{2}(0.8804)$ of Freundlich equation so that the behavior of the nitrite adsorption of this studied RHB followed the homogeneous adsorption of the mono molecular layer. 


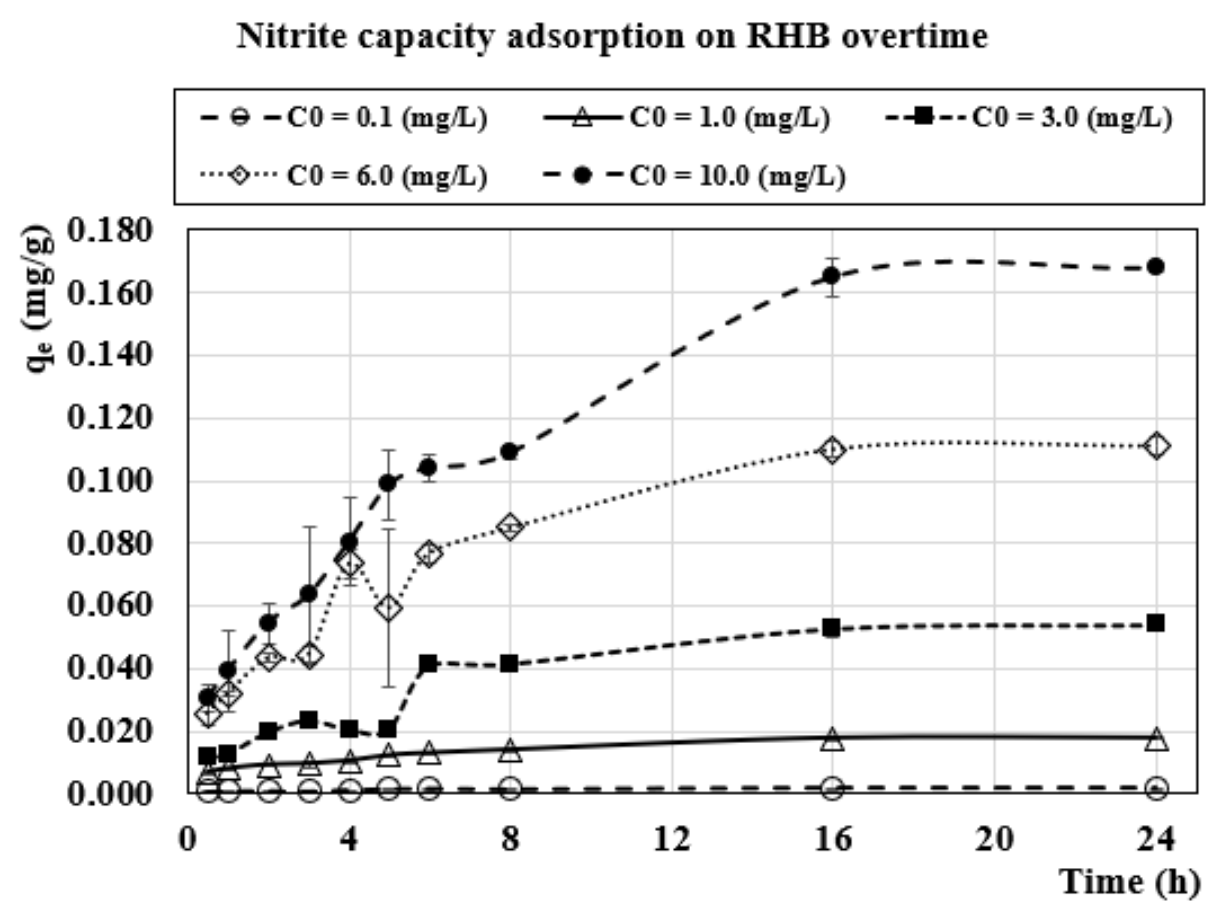

Figure 5. Effect of contact time and initial concentration to nitrite adsorption capacity onto RHB

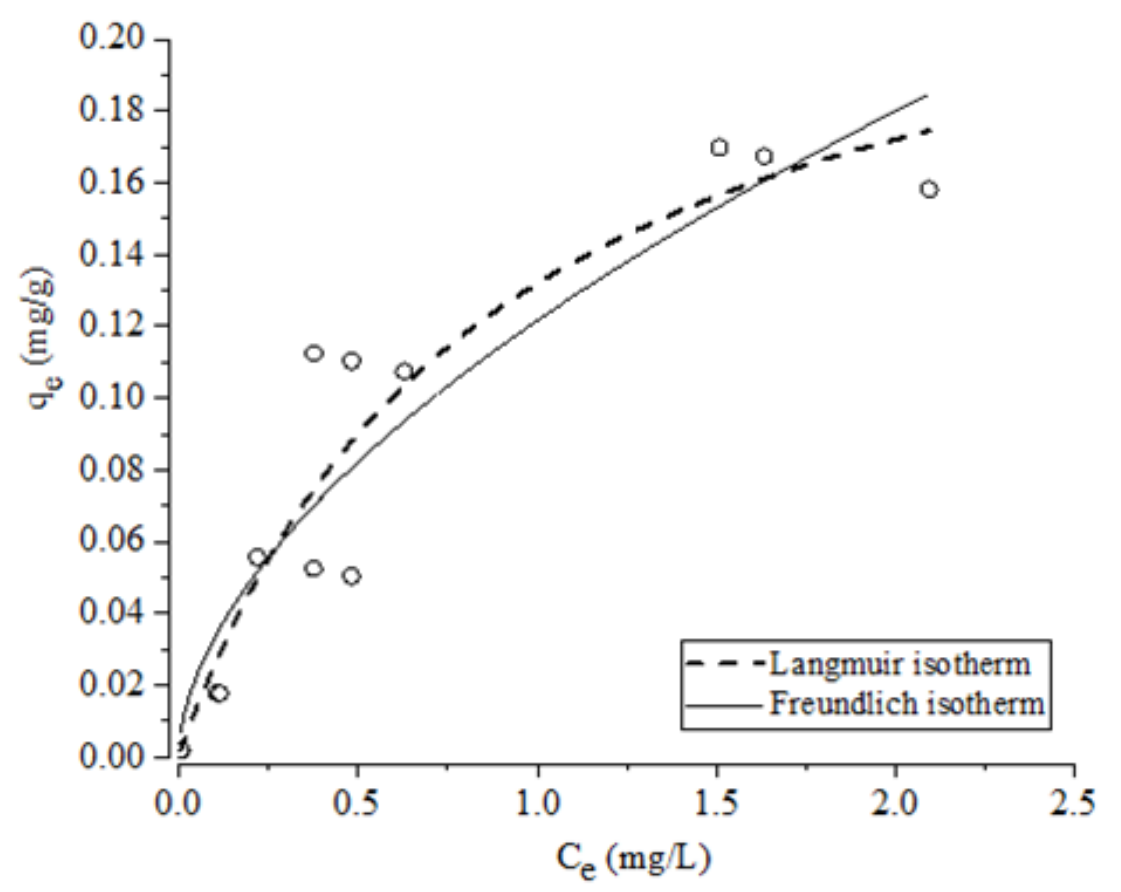

Figure 6. Langmuir and Freundlich isotherms for nitrite adsorption onto RHB

Table 3

Langmuir and Freundlich parameters for nitrite adsorption onto RHB at $28^{\circ} \mathrm{C}$

\begin{tabular}{cccccc}
\hline \multicolumn{3}{c}{ Langmuir isotherm } & \multicolumn{3}{c}{ Freundlich isotherm } \\
\hline $\mathrm{Q}^{0}{ }_{\max }(\mathrm{mg} / \mathrm{g})$ & $\mathrm{K}_{\mathrm{L}}(\mathrm{L} / \mathrm{mg})$ & $\mathrm{R}^{2}$ & $\mathrm{~K}_{\mathrm{F}}$ & $\mathrm{n}$ & $\mathrm{R}^{2}$ \\
\hline 0.2477 & 1.1381 & 0.9090 & 0.1215 & 1.7655 & 0.8804 \\
\hline
\end{tabular}

Source: The researcher's data analysis 


\subsubsection{Nitrate adsorption}

When increasing the initial nitrate concentration, there was a trend that adsorption capacity increases accordingly and reached an equilibrium at 8-hour contact time. Table 1 was used to check the validity of isotherms. The separation factor $\left(\mathrm{R}_{\mathrm{L}}\right)$ of Langmuir equation ranged $0.14-0.35$ and Freundlich exponent $(1 / \mathrm{n})$ was 0.44 that means both isotherms suitable for explaining the nitrate adsorption onto RHB. $\mathrm{R}^{2}(0.9380)$ of Freundlich equation was higher than $\mathrm{R}^{2}(0.9140)$ of Langmuir equation so that the behavior of the nitrate adsorption of this studied RHB followed the heterogeneous adsorption of the multi molecular layer rather than mono layer (Kizito et al., 2015).

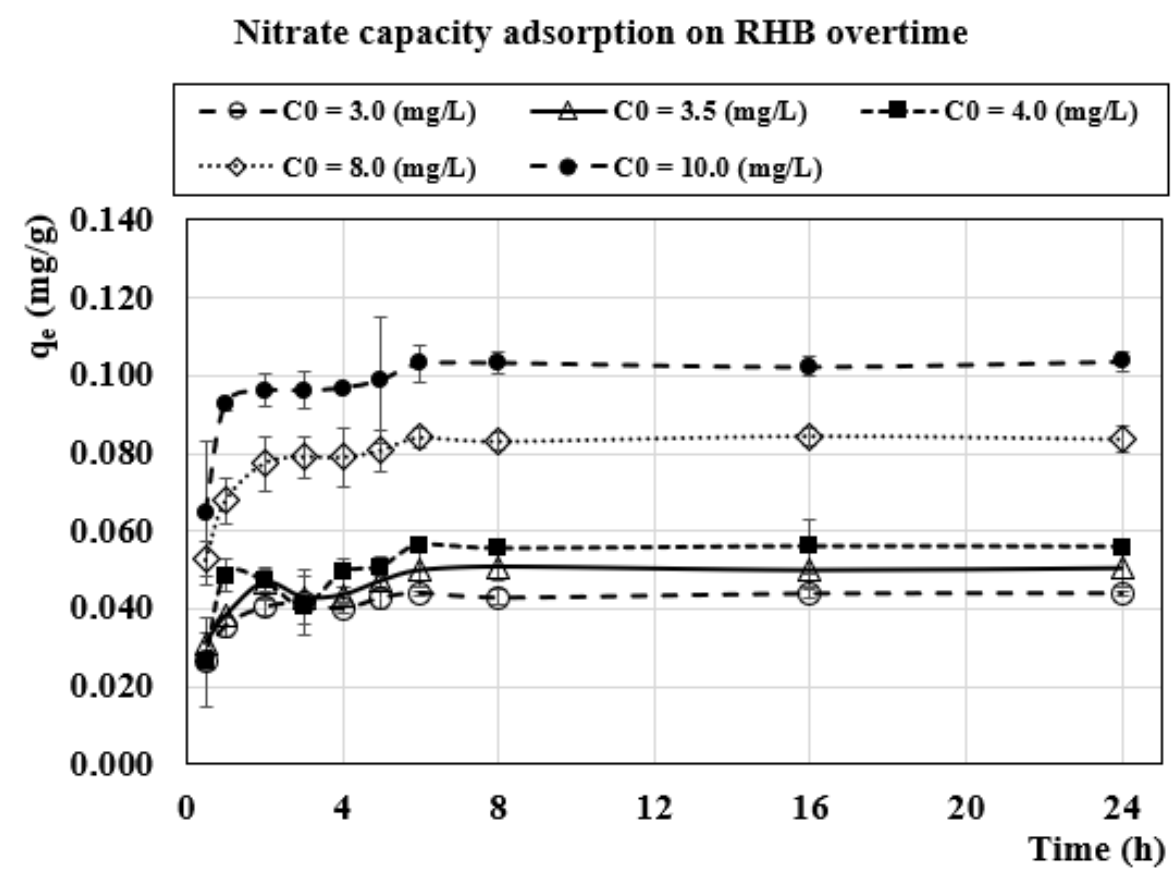

Figure 7. Effect of contact time and initial concentration to nitrate adsorption capacity onto RHB

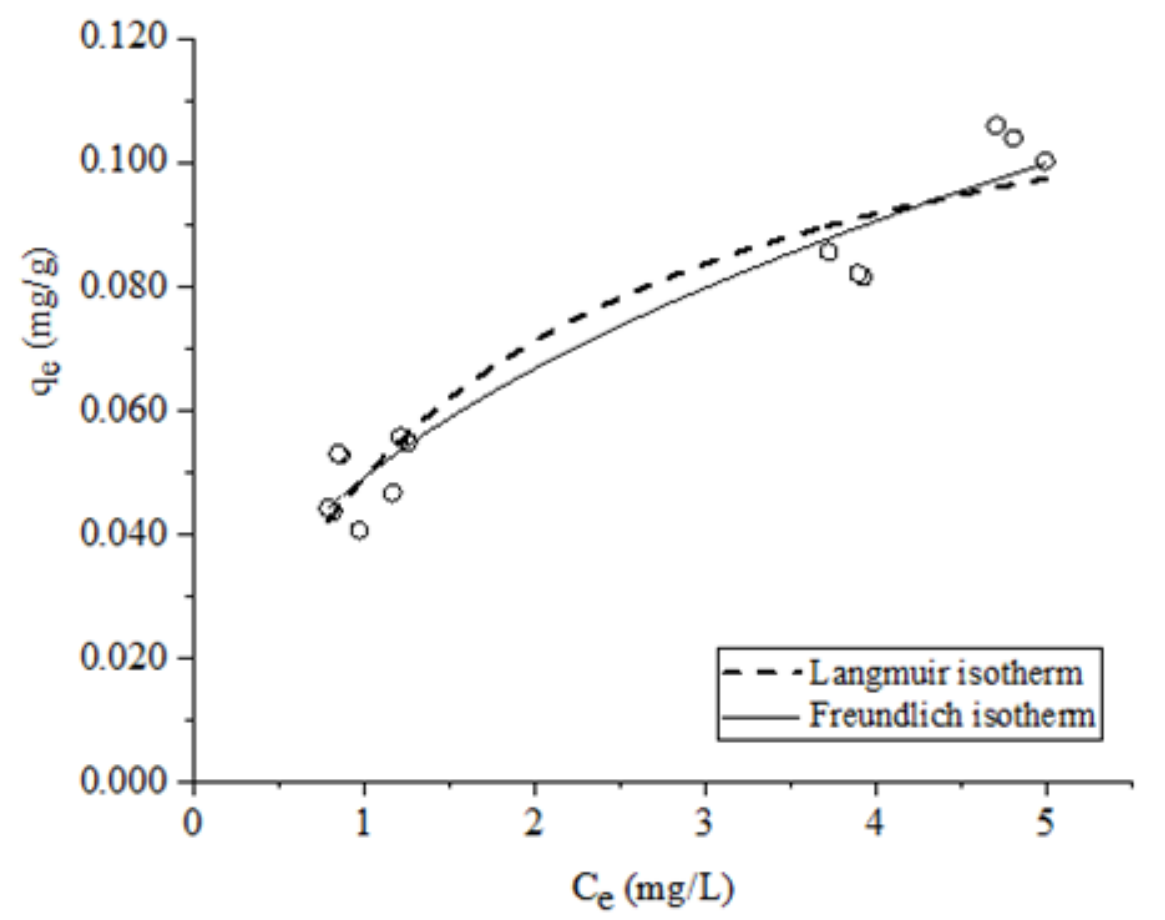

Figure 8. Langmuir and Freundlich isotherms for nitrate adsorption onto RHB 


\section{Table 4}

Langmuir and Freundlich parameters for nitrate adsorption onto RHB at $28{ }^{\circ} \mathrm{C}$

\begin{tabular}{cccccc}
\hline \multicolumn{3}{c}{ Langmuir isotherm } & \multicolumn{3}{c}{ Freundlich isotherm } \\
\hline $\mathrm{Q}^{0}{ }_{\max }(\mathrm{mg} / \mathrm{g})$ & $\mathrm{K}_{\mathrm{L}}(\mathrm{L} / \mathrm{mg})$ & $\mathrm{R}^{2}$ & $\mathrm{~K}_{\mathrm{F}}$ & $\mathrm{n}$ & $\mathrm{R}^{2}$ \\
\hline 0.1290 & 0.6142 & 0.9140 & 0.0491 & 2.27 & 0.9380 \\
\hline
\end{tabular}

Source: The researcher's data analysis

The studied RHB has a low adsorption capacity to ammonium, nitrite, and nitrate in comparison with other adsorbents as shown in Table 4. It could be explained that its original size (5-8 $\mathrm{mm})$ was selected for adsorption experiments. This is a trade-off in order to reduce the clogging when uses raw RHB as biofilter substrate in trickling filtration. Nevertheless, with a moderate adsorption capacity for nitrite $(0.2477 \mathrm{mg} / \mathrm{g})$, RHB would be a better choice to replace activated carbon for minimizing nitrite toxicity in aquaculture water thanks to its economical and environmental aspects.

\section{Table 5}

Comparison of RHB's adsorption capacity in this study with other biochar-based adsorbents

\begin{tabular}{|c|c|c|c|c|c|c|c|}
\hline Adsorbate & Adsorbent & $\begin{array}{c}\text { Particle } \\
\text { size }(\mathbf{m m})\end{array}$ & $\begin{array}{c}\text { Pyrolysis } \\
\text { temperature } \\
\left({ }^{\circ} \mathrm{C}\right)\end{array}$ & $\begin{array}{c}\text { Pyrolysis } \\
\text { time (h) }\end{array}$ & $\begin{array}{c}\text { Adsorption } \\
\text { temperature } \\
\left({ }^{\circ} \mathbf{C}\right)\end{array}$ & $\begin{array}{c}\text { Maximum } \\
\text { saturated } \\
\text { monolayer } \\
\text { adsorption } \\
\text { capacity } \mathbf{Q}^{0} \text { max } \\
(\mathrm{mg} / \mathrm{g})\end{array}$ & Reference \\
\hline \multirow{5}{*}{$\mathrm{NH}_{4}^{+}$} & $\begin{array}{l}\text { Rice husk } \\
\text { biochar }\end{array}$ & $5-8$ & $550^{\circ} \mathrm{C}$ & 3 & 28 & 0.1003 & This study \\
\hline & $\begin{array}{l}\text { Pitaya peel } \\
\text { biochar }\end{array}$ & Powder & $400{ }^{\circ} \mathrm{C}$ & 2 & 25 & 2.65 & (Hu et al., 2020) \\
\hline & $\begin{array}{c}\text { Thalia } \\
\text { dealbata } \\
\text { biochar }\end{array}$ & $<0.5$ & $500{ }^{\circ} \mathrm{C}$ & 2 & 25 & 1.91 & (Cui et al., 2016) \\
\hline & $\begin{array}{l}\text { Rice husk } \\
\text { biochar }\end{array}$ & $0.25-1.25$ & $600{ }^{\circ} \mathrm{C}$ & 10 & 25 & 39.8 & $\begin{array}{c}\text { (Kizito et al., } \\
\text { 2015) }\end{array}$ \\
\hline & $\begin{array}{l}\text { Rice husk } \\
\text { charcoal }\end{array}$ & - & $300{ }^{\circ} \mathrm{C}$ & - & 25 & 2.60 & $\begin{array}{c}\text { (Han, Zhao, } \\
\text { Dou, Jing, } \\
\text { \& Zhu, 2013) }\end{array}$ \\
\hline \multirow{3}{*}{$\mathrm{NO}_{2}^{-}$} & $\begin{array}{l}\text { Rice husk } \\
\text { biochar }\end{array}$ & $5-8$ & $550{ }^{\circ} \mathrm{C}$ & 3 & 28 & 0.2477 & This study \\
\hline & Hydrotalcite & - & - & - & 25 & 46.3 & $\begin{array}{c}\text { (Ogata et al., } \\
2018)\end{array}$ \\
\hline & $\begin{array}{l}\text { Rice straw- } \\
\text { derived } \\
\text { activated } \\
\text { carbon }\end{array}$ & - & $650{ }^{\circ} \mathrm{C}$ & 1 & 25 & 1.24 & $\begin{array}{l}\text { (Hamed, Yakout, } \\
\text { \& Hassan, 2013) }\end{array}$ \\
\hline
\end{tabular}




\begin{tabular}{|c|c|c|c|c|c|c|c|}
\hline Adsorbate & Adsorbent & $\begin{array}{c}\text { Particle } \\
\text { size }(\mathbf{m m})\end{array}$ & $\begin{array}{c}\text { Pyrolysis } \\
\text { temperature } \\
\left({ }^{\circ} \mathbf{C}\right)\end{array}$ & $\begin{array}{c}\text { Pyrolysis } \\
\text { time (h) }\end{array}$ & $\begin{array}{c}\text { Adsorption } \\
\text { temperature } \\
\left({ }^{\circ} \mathbf{C}\right)\end{array}$ & $\begin{array}{c}\text { Maximum } \\
\text { saturated } \\
\text { monolayer } \\
\text { adsorption } \\
\text { capacity } \mathbf{Q}^{0}{ }_{\text {max }} \\
(\mathbf{m g} / \mathbf{g})\end{array}$ & Reference \\
\hline & $\begin{array}{l}\text { Calcined } \\
\text { hydrotalcite }\end{array}$ & 0.149 & - & - & 25 & 37.17 & (Wan et al., 2012) \\
\hline & $\begin{array}{l}\text { Wood- } \\
\text { derived } \\
\text { activated } \\
\text { carbon }\end{array}$ & $<0.125$ & - & - & 29 & 2.19 & (Shabir, 2010) \\
\hline \multirow{5}{*}{$\mathrm{NO}_{3}^{-}$} & $\begin{array}{l}\text { Rice husk } \\
\text { biochar }\end{array}$ & $5-8$ & $550{ }^{\circ} \mathrm{C}$ & 3 & 28 & 0.1290 & This study \\
\hline & $\begin{array}{l}\text { Hydrogel- } \\
\text { rice husk } \\
\text { biochar }\end{array}$ & Powder & $500{ }^{\circ} \mathrm{C}$ & 1 & 25 & 1.53 & $\begin{array}{c}\text { (Afjeh, Marandi, } \\
\text { \& Zohuriaan- } \\
\text { Mehr, 2020) }\end{array}$ \\
\hline & $\begin{array}{l}\text { Rice husk } \\
\text { biochar }\end{array}$ & - & $600{ }^{\circ} \mathrm{C}$ & 0.5 & 25 & 0.497 & $\begin{array}{c}\text { (Shukla et al., } \\
\text { 2019) }\end{array}$ \\
\hline & $\begin{array}{c}\text { Corn stover } \\
\text { biochar }\end{array}$ & $<0.5$ & $600{ }^{\circ} \mathrm{C}$ & 2 & - & 1.5 & (Fidel et al., 2018) \\
\hline & $\begin{array}{l}\text { Sugarcane } \\
\text { bagasse } \\
\text { biochar }\end{array}$ & - & $600{ }^{\circ} \mathrm{C}$ & 4 & 22 & 11.56 & $\begin{array}{c}\text { (Hafshejani et al., } \\
\text { 2016) }\end{array}$ \\
\hline
\end{tabular}

Note: the minus sign means not shown in literature.

Source: The researcher's data analysis

\section{Conclusions}

Biochar has been received great attention recent years due to its novel structure and characteristics that let it become a promising candidate for bioremediation in both targets costefficient and sustainable (Lu et al., 2020). The findings in this paper that raw RHB can be used for nitrogen removal because its adsorption capacity towards ammonium, nitrite, and nitrate ranging from $0.10-0.24 \mathrm{mg} / \mathrm{g}$ that adequately satisfies for controlling water quality in RAS. Nevertheless, raw biochar is not recommended as a silver bullet unless it should be engineered for specific application that can unlock fully its potential. It means the continuation of biochar research would focus on integration biotic and abiotic agents on biochar matrix to make it more effective in different operation settings.

\section{ACKNOWLEDGEMENTS}

We would like to express our very great appreciation to Biotechnology Center of Ho Chi Minh City for funding this research project coded MT03/18-20 as well as providing necessary equipments for our hard-working internship students doing their best. 


\section{References}

Afjeh, M. S., Marandi, G. B., \& Zohuriaan-Mehr, M. J. (2020). Nitrate removal from aqueous solutions by adsorption onto hydrogel-rice husk biochar composite. Water Environment Research, 92(6), 934-947.

Afkhami, A., Madrakian, T., \& Karimi, Z. (2007). The effect of acid treatment of carbon cloth on the adsorption of nitrite and nitrate ions. Journal of Hazardous Materials, 144(1/2), 427431.

Ahmad, M., Rajapaksha, A. U., Lim, J. E., Zhang, M., Bolan, N., Mohan, D., ... Ok, Y. S. (2014). Biochar as a sorbent for contaminant management in soil and water: A review. Chemosphere, 99, 19-33.

Ahmed, S., \& Hussain, C. M. (2018). Green and sustainable advanced materials. Volume 2: Applications. Beverly, MA: Wiley-Scrivener.

Appel, J. (1973). Freundlich's adsorption isotherm. Surface Science, 39(1), 237-244.

Badiola, M., Mendiola, D., \& Bostock, J. (2012). Recirculating Aquaculture Systems (RAS) analysis: Main issues on management and future challenges. Aquacultural Engineering, 51, 26-35.

Bakatula, E. N., Richard, D., Neculita, C. M., \& Zagury, G. J. (2018). Determination of point of zero charge of natural organic materials. Environmental Science and Pollution Research, 25(8), 7823-7833.

Bolster, C. H., \& Hornberger, G. M. (2007). On the use of linearized Langmuir equations. Soil Science Society of America Journal, 71(6), 1796-1806.

Brewer, C. E., Schmidt-Rohr, K., Satrio, J. A., \& Brown, R. C. (2009). Characterization of biochar from fast pyrolysis and gasification systems. Environmental Progress \& Sustainable Energy, 28(3), 386-396.

Bui, A. T. L. (2016). Nghiên cưu chế tạo vật liệu hấp phu tù xơ dùa để xủ lý amoni trong nuớc thải bệnh viện [Research on fabrication of adsorbent materials from coconut fiber to treat ammonium in hospital wastewater] (Master's thesis). Đại học Khoa học Tự Nhiên - Đại học Quốc gia Hà Nội.

Crini, G., \& Lichtfouse, E. (2018). Green Adsorbents for pollutant removal: Innovative materials. New York, NY: Springer International Publishing.

Cui, X., Hao, H., Zhang, C., He, Z., \& Yang, X. (2016). Capacity and mechanisms of ammonium and cadmium sorption on different wetland-plant derived biochars. Science of The Total Environment, 539, 566-575.

Dai, Y., Zhang, N., Xing, C., Cui, Q., \& Sun, Q. (2019). The adsorption, regeneration and engineering applications of biochar for removal organic pollutants: A review. Chemosphere, 223, 12-27.

Enaime, G., Baçaoui, A., Yaacoubi, A., \& Lübken, M. (2020). Biochar for wastewater treatment Conversion Technologies and applications. Applied Sciences, 10(10), Article 3492.

Essandoh, M., Kunwar, B., Pittman, C. U., Mohan, D., \& Mlsna, T. (2015). Sorptive removal of salicylic acid and ibuprofen from aqueous solutions using pine wood fast pyrolysis biochar. Chemical Engineering Journal, 265, 219-227. 
FAO. (2020). The state of world fisheries and aquaculture 2020: Sustainability in action. Rome, Italy: FAO.

Ferreira, C. I. A., Calisto, V., Otero, M., Nadais, H., \& Esteves, V. I. (2016). Comparative adsorption evaluation of biochars from paper mill sludge with commercial activated carbon for the removal of fish anaesthetics from water in Recirculating Aquaculture Systems. Aquacultural Engineering, 74, 76-83.

Fidel, R. B., Laird, D. A., \& Spokas, K. A. (2018). Sorption of ammonium and nitrate to biochars is electrostatic and pH-dependent. Scientific Reports, 8(1), Article 17627.

Foo, K. Y., \& Hameed, B. H. (2010). Insights into the modeling of adsorption isotherm systems. Chemical Engineering Journal, 156(1), 2-10.

Freundlich, H. (1907). Über die Adsorption in Lösungen [About adsorption in solutions]. Zeitschrift für Physikalische Chemie, 57(1), 385-470.

Gai, X., Wang, H., Liu, J., Zhai, L., Liu, S., Ren, T., \& Liu, H. (2014). Effects of feedstock and pyrolysis temperature on biochar adsorption of ammonium and nitrate. PLoS ONE, 9(12), Article e113888.

Ghosal, P. S., \& Gupta, A. K. (2017). Determination of thermodynamic parameters from Langmuir isotherm constant-revisited. Journal of Molecular Liquids, 225, 137-146.

Gladek, E., Fraser, M., Roemers, G., Muñoz, O. S., Kennedy, E., \& Hirsch, P. (2017). The global food system: An analysis. Retrieved January 10, 2021, from https://www.metabolic.nl/publication/global-food-system-an-analysis/

Hafshejani, L. D., Hooshmand, A., Naseri, A. A., Mohammadi, A. S., Abbasi, F., \& Bhatnagar, A. (2016). Removal of nitrate from aqueous solution by modified sugarcane bagasse biochar. Ecological Engineering, 95, 101-111.

Hamed, M. M., Yakout, S. M., \& Hassan, H. S. (2013). Solid phase extraction of nitrate and nitrite anions using naturally and available sorbent. Journal of Radioanalytical and Nuclear Chemistry, 295(1), 697-708.

Han, J. G., Zhao, G., Dou, L. S., Jing, Y. J., \& Zhu, Y. L. (2013). Adsorption of ammonium nitrogen in water by rice husk charcoal: A simulation study. Advanced Materials Research, 781-784, 2063-2066.

Herath, I., Kumarathilaka, P., Al-Wabel, M. I., Abduljabbar, A., Ahmad, M., Usman, A. R. A., \& Vithanage, M. (2016). Mechanistic modeling of glyphosate interaction with rice husk derived engineered biochar. Microporous and Mesoporous Materials, 225, 280-288.

Hu, X., Zhang, X., Ngo, H. H., Guo, W., Wen, H., Li, C., ... Ma, C. (2020). Comparison study on the ammonium adsorption of the biochars derived from different kinds of fruit peel. Science of The Total Environment, 707, Article 135544.

Huang, X., Liu, Y., Liu, S., Tan, X., Ding, Y., Zeng, G., ... Zheng, B. (2016). Effective removal of $\mathrm{Cr}(\mathrm{vi})$ using $\beta$-cyclodextrin-chitosan modified biochars with adsorption/reduction bifuctional roles. RSC Advances, 6(1), 94-104.

International Biochar Initiative. (2015). Standardized product definition and product testing guidelines for biochar that is used in soil. Retrieved January 11, 2021, from https://biocharinternational.org/characterizationstandard/ 
Inyang, M., Gao, B., Yao, Y., Xue, Y., Zimmerman, A. R., Pullammanappallil, P., \& Cao, X. (2012). Removal of heavy metals from aqueous solution by biochars derived from anaerobically digested biomass. Bioresource Technology, 110, 50-56.

Kizito, S., Wu, S., Kirui, W. K., Lei, M., Lu, Q., Bah, H., \& Dong, R. (2015). Evaluation of slow pyrolyzed wood and rice husks biochar for adsorption of ammonium nitrogen from piggery manure anaerobic digestate slurry. Science of The Total Environment, 505, 102-112.

Langmuir, I. (1918). The adsorption of gases on plane surfaces of glass, mica and platinum. Journal of the American Chemical Society, 40(9), 1361-1403.

Lehmann, J., \& Joseph, S. (2015). Biochar for environmental management: Science, technology and implementation (2nd ed.). London, UK: Routledge, Taylor \& Francis Group.

Liang, P., Yu, H., Huang, J., Zhang, Y., \& Cao, H. (2016). The review on adsorption and removing ammonia nitrogen with biochar on its mechanism. MATEC Web of Conferences, 67, 1-11.

Lu, L., Yu, W., Wang, Y., Zhang, K., Zhu, X., Zhang, Y., ... Chen, B. (2020). Application of biochar-based materials in environmental remediation: From multi-level structures to specific devices. Biochar, 2(1), 1-31.

Milla, O. V., Rivera, E. B., Huang, W.-J., Chien, C.-, C., \& Wang, Y.-M. (2013). Agronomic properties and characterization of rice husk and wood biochars and their effect on the growth of water spinach in a field test. Journal of Soil Science and Plant Nutrition, 13(2), 251-266.

Mohan, D., Sarswat, A., Ok, Y. S., \& Pittman, C. U. (2014). Organic and inorganic contaminants removal from water with biochar, a renewable, low cost and sustainable adsorbent - A critical review. Bioresource Technology, 160, 191-202.

Nguyen, L. H., Van, H. T., Nguyen, Q. T., Nguyen, T. H., Nguyen, T. B. L., Nguyen, V. Q., ... Le, H. S. (2021). Paper waste sludge derived-hydrochar modified by iron (III) chloride for effective removal of $\mathrm{Cr}(\mathrm{VI})$ from aqueous solution: Kinetic and isotherm studies. Journal of Water Process Engineering, 39, Article 101877.

Ogata, F., Nagai, N., Kariya, Y., Nagahashi, E., Kobayashi, Y., Nakamura, T., \& Kawasaki, N. (2018). Adsorption of nitrite and nitrate ions from an aqueous solution by Fe-Mg-type hydrotalcites at different molar ratios. Chemical and Pharmaceutical Bulletin, 66(4), 458-465.

Poor, C., \& Mohamed, M. (2020). Effect of biochar on metals and nutrient removal in bioretention systems. In World environmental and water resources congress 2020 (pp. 73-83).

Pham, L. T. N. (2016). Nghiên cứu biến tính than hoạt tính chế tạo từ các phế phẩm nông nghiệp làm vật liệu hấp phụ xử lý amoni trong nước [Study on modified activated carbon fabricated from agricultural residues as an adsorbent for treatment of ammonium in water]. Tap Chi Khoa Học Kỹ Thuật và Môi Trường, 52, 129-137.

Shabir, M. (2010). Effect of electrolytes on the adsorption of nitrite and nitrate from aqueous solutions by activated carbon. Journal of Applied Sciences and Environmental Management, 14(3), 5-11.

Shukla, N., Sahoo, D., \& Remya, N. (2019). Biochar from microwave pyrolysis of rice husk for tertiary wastewater treatment and soil nourishment. Journal of Cleaner Production, 235, 1073-1079. 
Takeuchi, T. (2017). Application of Recirculating Aquaculture Systems in Japan. Tokyo, Japan: Springer.

Timmons, M. B., Guerdat, T., \& Vinci, B. J. (2018). Recirculating aquaculture (4th ed.). New York, NY: Ithaca Publishing Company LLC.

Tran, H. N., You, S.-J., Hosseini-Bandegharaei, A., \& Chao, H.-P. (2017). Mistakes and inconsistencies regarding adsorption of contaminants from aqueous solutions: A critical review. Water Research, 120, 88-116.

Van der Bruggen, B. (2015). Freundlich isotherm [Friendly isothermal]. In E. Drioli \& L. Giorno (Eds.), Encyclopedia of membranes (pp. 1-2). Berlin, Heidelberg: Springer.

Vu, M. T., \& Trinh, T. V. (2016). Nghiên cứu khả năng xử lý amoni trong môi trường nước của than sinh học từ lõi ngô biến tính bằng $\mathrm{H}_{3} \mathrm{PO}_{4}$ và $\mathrm{NaOH}$ [Study on the ability to treat ammonium in aqueous environment of biochar from maize modified by $\mathrm{H} 3 \mathrm{PO} 4$ and $\mathrm{NaOH}]$. Tạp Chí Khoa Học ĐHQGHN: Các Khoa Học Trái Đất và Môi Truờng, 32(1S), 274-281.

Wan, D., Liu, H., Liu, R., Qu, J., Li, S., \& Zhang, J. (2012). Adsorption of nitrate and nitrite from aqueous solution onto calcined $(\mathrm{Mg}-\mathrm{Al})$ hydrotalcite of different $\mathrm{Mg} / \mathrm{Al}$ ratio. Chemical Engineering Journal, 195-196, 241-247.

Wang, S., Gao, B., Zimmerman, A. R., Li, Y., Ma, L., Harris, W. G., \& Migliaccio, K. W. (2015). Removal of arsenic by magnetic biochar prepared from pinewood and natural hematite. Bioresource Technology, 175, 391-395.

Worch, E. (2012). Adsorption technology in water treatment: Fundamentals, processes, and modeling. Berlin, Germany: Walter de Gruyter.

Wu, P., Wang, Z., Wang, H., Bolan, N. S., Wang, Y., \& Chen, W. (2020). Visualizing the emerging trends of biochar research and applications in 2019: A scientometric analysis and review. Biochar, 2(2), 135-150.

Yakout, S. M., \& Mostafa, A. A. (2014). Removal of nitrite from aqueous solution by active carbon: Adsorption kinetics modeling. Journal of Animal and Veterinary Advances, 13(9), 558-563.

Zhang, M., Song, G., Gelardi, D. L., Huang, L., Khan, E., Mašek, O., ... Ok, Y. S. (2020). Evaluating biochar and its modifications for the removal of ammonium, nitrate, and phosphate in water. Water Research, 186, Article 116303. 